\title{
OCEANIC RADIOCARBON AND TRITIUM ON A TRANSECT BETWEEN AUSTRALIA AND BALI (EASTERN INDIAN OCEAN)
}

\begin{abstract}
Viviane Leboucher $^{1} \cdot$ Philippe Jean-Baptiste $^{1,2} \cdot$ Elise Fourré $^{1}$ - Maurice Arnold ${ }^{1} \bullet$ Michèle Fieux $^{3}$
ABSTRACT. Results are presented of radiocarbon and tritium measurements along a transect between the Australian continental shelf and the Indonesian coast of Bali. The stations lie in the easternmost part of the Indian Ocean, close to the sills over which the Indonesian throughflow (ITF) makes its way to the Indian Ocean. The present data, obtained as part of the JavaAustralia Dynamics Experiment (JADE) in August 1989, complement the WOCE ${ }^{14} \mathrm{C}$ and tritium data set on both sides of the Indonesian archipelago and give us the opportunity to discuss the origin of the water masses and timescale of the throughflow. Both tracers point to a north equatorial Pacific origin of the waters. The comparison of the tritium inventories in the Pacific North Equatorial Current and along the JADE transect suggests a minimum transit time of the waters across the Indonesian seaways of the order of 5 to $6 \mathrm{yr}$, corresponding to a throughflow $<18 \times 10^{6} \mathrm{~m}^{3} / \mathrm{s}$.
\end{abstract}

\section{INTRODUCTION}

The invasion of bomb radiocarbon in the ocean has been used for several decades to study ocean circulation and ventilation processes. However, very few measurements exist for the Indonesian throughflow (Broecker et al. 1986a). Here, we report ${ }^{14} \mathrm{C}$ and tritium measurements at the exit of the Indonesian throughflow (ITF) on a transect between Australia and Bali in the easternmost part of the Indian Ocean (Figure 1). The section crosses all the water masses coming from the western Pacific through the Indonesian seas. Therefore, it represents an open window on the ITF, which constitutes a major return path for the warm North Pacific tropical waters to the Atlantic, and plays an important role in the global ocean circulation and climate regulation (Gordon and Fine 1996).

The samples were taken during the JADE-89 cruise (Java-Australia Dynamics Experiment) in August 1989, about a decade after the end of the GEOSECS Indian Ocean program and a few years prior to the start of the World Ocean Circulation Experiment (WOCE). On the Pacific side, recently available data from the WOCE sections in the western Pacific (Key et al. 2002; Schlosser 2002; Jenkins 2002; Kumamoto et al. 2002) represent an extremely valuable data set in the context of our study. On the Indian side, the eastermost WOCE sections (Schlosser 2002; Jenkins 2002) do not extend beyond $111^{\circ} \mathrm{E}$. Owing to its position closer to the passages by which the Indonesian waters enter the Indian Ocean, the JADE-89 transect represents a unique link between the Indian and Pacific data sets.

\section{HYDROGRAPHY AND WATER MASSES CHARACTERISTICS}

The main hydrographic characteristics of the water masses along the JADE transect have been described in detail by Fieux et al. (1994) using the distribution of potential temperature, salinity, and dissolved oxygen. At the surface, a wedge of low salinity/high temperature layer (Figure 2a,b), which is more pronounced in the northern part of the section, marks the influx of water of Indonesian origin flowing out of the Savu and Timor Seas. The low salinity results both from the characteristics of the incoming Indonesian waters and from local excess of precipitation over evaporation, which is typical of this region of the Indian Ocean under the Inter-Tropical Convergence Zone

\footnotetext{
${ }^{1}$ Laboratoire des Sciences du Climat et de l'Environnement, IPSL, CEA-CNRS, CEA/Saclay, F91191-Gif/Yvette cedex, France.

${ }^{2}$ Corresponding author. Email: pjb@lsce.saclay.cea.fr.

${ }^{3}$ Laboratoire d'Océanographie Dynamique et de Climatologie, Université Paris VI, F75252 - Paris cedex 05, France.
}

(C) 2004 by the Arizona Board of Regents on behalf of the University of Arizona Proceedings of the 18th International Radiocarbon Conference, edited by N Beavan Athfield and R J Sparks RADIOCARBON, Vol 46, Nr 2, 2004, p 567-581 


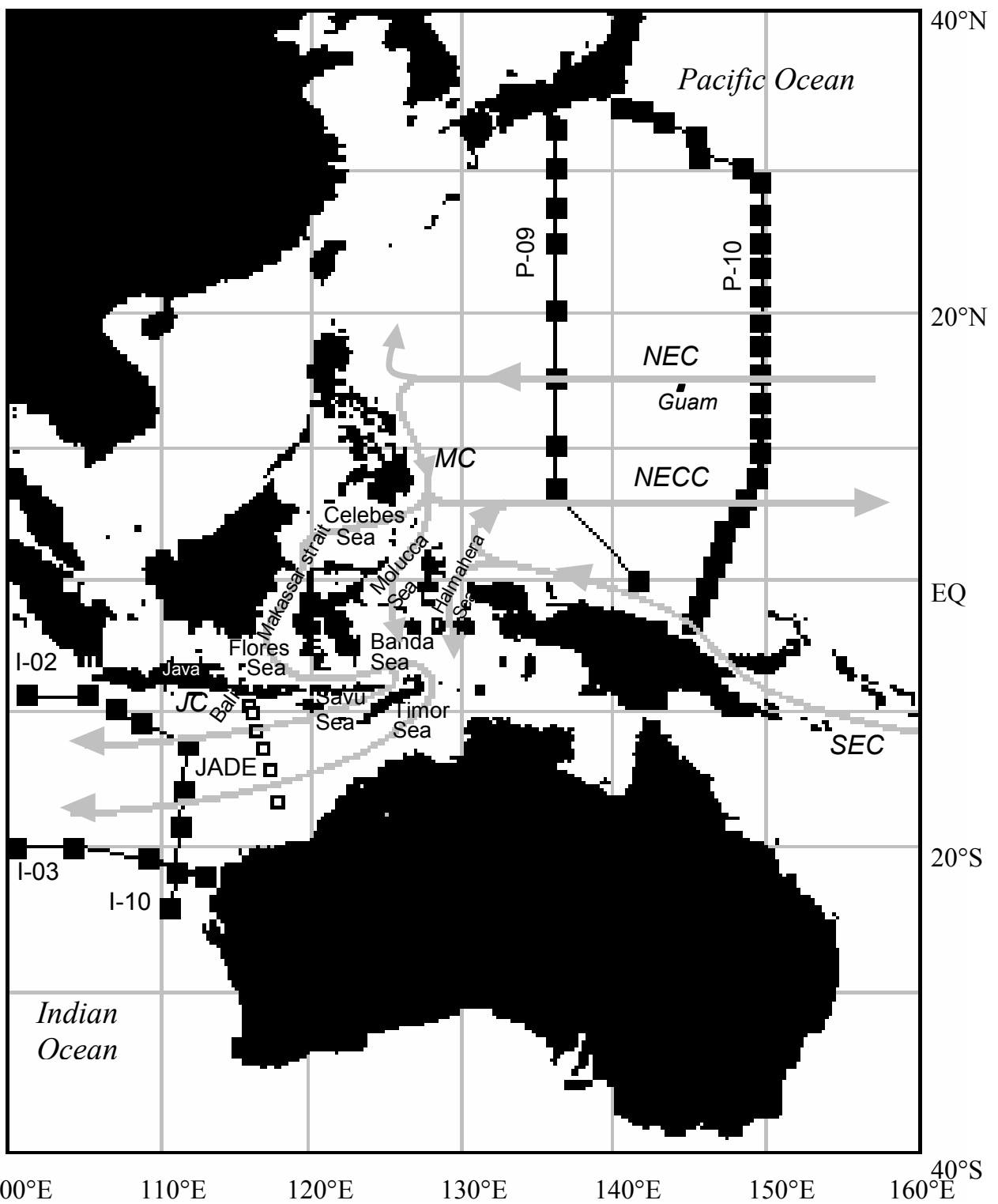

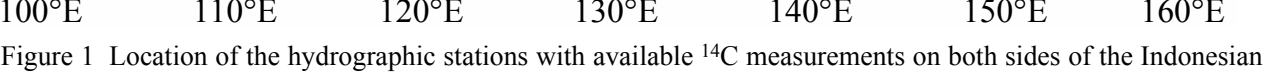
throughflow (the WOCE cruises and JADE-89 transect are indicated by solid and open squares, respectively), and schematic diagram of major currents. NEC: North Equatorial Current, NECC: North Equatorial CounterCurrent, $S E C$ : South Equatorial Current, $M C$ : Mindanoa Current, JC: Java Current.

(ITCZ). Next to Bali, all the isolines slope upwards due to the presence of a strong coastal upwelling. This upwelling is created by the sustained easterly winds during this phase of the monsoon. These winds also generate a strong westward surface current along the coast, the Java current, which reverses with the monsoons. Below the thermocline, the characteristics of the water masses reveal a sharp front at $13^{\circ} 30^{\prime} \mathrm{S}$. South of this front, the salinity maximum between $150 \mathrm{~m}$ and $450 \mathrm{~m}$ identifies the South Indian Ocean subtropical water (Figure 2b). North of the front, the lower salinity is representative of the waters originating from the Indonesian seas. 


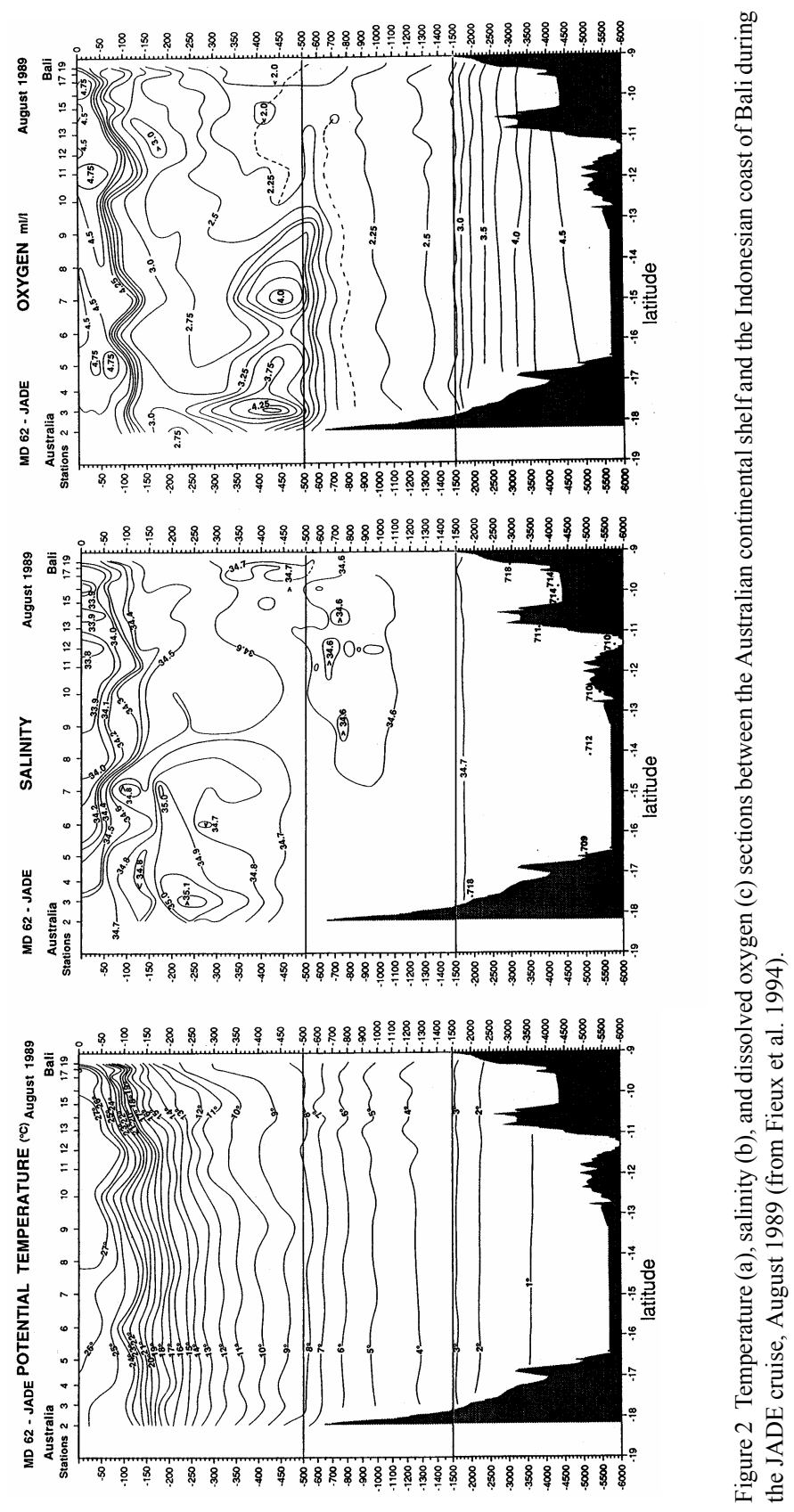


Between $350 \mathrm{~m}$ and $600 \mathrm{~m}$, the sharp oxygen maximum in the southern part of the section (Figure 2c) traces the Indian Ocean central water, also named Subantarctic Mode Waters (Warren 1981; McCartney 1982). In the north, trapped along the coast, appears a water mass characterized by a higher salinity $\mathrm{S}>34.7 \mathrm{psu}$ and lower oxygen content $\mathrm{O}_{2}<89 \mu \mathrm{mol} / \mathrm{kg}(=2.0 \mathrm{~mL} / \mathrm{l})$, which corresponds to northern Indian Ocean waters originating from the Arabian Sea (Fieux et al. 1994).

Between $750 \mathrm{~m}$ and $1000 \mathrm{~m}$, north of $15^{\circ} \mathrm{S}$, the weak salinity minimum ( $<34.6 \mathrm{psu}$ ) points to the presence of the Banda Intermediate waters. This deep Indonesian throughflow is also well depicted by its sharp ${ }^{3} \mathrm{He}$ anomaly, which is characteristic of the Pacific waters (Jean-Baptiste et al. 1997; Top et al. 1997).

From the temperature and salinity data, Fieux et al. (1994) calculated at the time of the JADE cruise a net geostrophic transport of $18.6 \times 10^{6} \mathrm{~m}^{3} / \mathrm{s}$ directed towards the Indian Ocean. Seventy percent of this flow occurs in the $0-200 \mathrm{~m}$ layer, between the coast of Bali and the $13^{\circ} 30-15^{\circ} \mathrm{S}$ frontal zone, thus representing the core of the Pacific-Indian throughflow.

\section{EXPERIMENTAL METHODS}

The ${ }^{14} \mathrm{C}$ samples were treated according to the procedure described by Bard et al. (1987) and Leboucher et al. (1999). Seawater was collected in 12-L Niskin bottles. For each sample, $500 \mathrm{~mL}$ of water was transferred to a glass bottle and poisoned with $1 \mathrm{~mL}$ of saturated $\mathrm{HgCl}_{2}$ solution. In the laboratory, $\mathrm{CO}_{2}$ was extracted by adding $2 \mathrm{~mL}$ of $15 \mathrm{~N} \mathrm{H}_{3} \mathrm{PO}_{4}$ to a $100-\mathrm{mL}$ seawater aliquot in a vacuumtight system sparged by helium gas (flow rate $80 \mathrm{~mL} / \mathrm{min}$ ); the extraction required $1 \mathrm{hr}$. Water was removed by a trap at $-80{ }^{\circ} \mathrm{C}$ and $\mathrm{CO}_{2}$ was trapped at $-180{ }^{\circ} \mathrm{C}$ using liquid nitrogen. Then, $\mathrm{CO}_{2}$ was reduced to graphite by hydrogen at $850^{\circ} \mathrm{C}$ during $6-8 \mathrm{hr}$ in the presence of iron powder. Three targets were made from the carbon-iron mixture for accelerator mass spectrometry (AMS). The ${ }^{14} \mathrm{C}$ measurements were performed at the Tandetron AMS facility in Gif-sur-Yvette. The data (Table 1) are expressed as $\Delta^{14} \mathrm{C}$. Two targets per sample were analyzed to obtain the required precision of $\pm 3 \%$.

Samples were also taken for tritium $\left({ }^{3} \mathrm{H}\right)$ analysis. Since ${ }^{14} \mathrm{C}$ and ${ }^{3} \mathrm{H}$ were released together by the atmospheric nuclear detonations of the late 1950s and early 1960s, both isotopes constitute complementary tracers for oceanographic studies. The ${ }^{3} \mathrm{H}$ measurements were performed at the helium isotope facility in Saclay using the ${ }^{3} \mathrm{He}$ ingrowth method (Jean-Baptiste et al. 1992). Briefly, the seawater samples were stored in 500-mL Pyrex bottles. In the laboratory, the water was degassed under high vacuum to remove the naturally dissolved ${ }^{3} \mathrm{He}$, and sealed in a Corning 1724 glass bulb. The bulbs were stored at $-20{ }^{\circ} \mathrm{C}$ to minimize ${ }^{3} \mathrm{He}$ diffusion through the walls during the storage period (Jean-Baptiste et al. 1989). After 12 to 18 months, the ${ }^{3} \mathrm{He}$ produced by the decay of tritium was measured on a MAP 215-50 mass spectrometer, permitting the determination of the tritium content of the water. The data are expressed in Tritium Unit (TU) at the date of sampling (1 TU corresponds to a $\mathrm{T} / \mathrm{H}$ ratio of $10^{-18}$ ). The precision on the tritium concentration is better than $0.01 \mathrm{TU}$.

\section{RESULTS}

\section{Vertical Profiles and Sections}

The ${ }^{14} \mathrm{C}$ and tritium results are summarized in Table 1. The vertical profiles are plotted in Figure 3. Below the shallow mixed layer, both transient tracer concentrations decrease sharply. Deeper than $1000 \mathrm{~m}$ to $1500 \mathrm{~m}$, tritium and ${ }^{14} \mathrm{C}$ concentrations fall to their natural background.

The $\Delta^{14} \mathrm{C}$ and ${ }^{3} \mathrm{H}$ vertical sections along the Australia-Bali transect are displayed in Figure 4. Surface and intermediate depth isolines are nearly horizontal, following those of temperature. The 
Table 1 JADE august $1989 \Delta^{14} \mathrm{C}$ and tritium results.

\begin{tabular}{|c|c|c|c|c|c|c|c|c|}
\hline $\begin{array}{l}\text { Depth } \\
\text { (m) }\end{array}$ & $\begin{array}{c}\text { Tritium } \\
\text { (TU) }\end{array}$ & $\begin{array}{c}\Delta^{14} \mathrm{C} \\
(\%)\end{array}$ & $\begin{array}{l}\text { Depth } \\
\text { (m) }\end{array}$ & $\begin{array}{c}\text { Tritium } \\
\text { (TU) }\end{array}$ & $\begin{array}{c}\Delta^{14} \mathrm{C} \\
(\% o)\end{array}$ & $\begin{array}{l}\text { Depth } \\
(\mathrm{m})\end{array}$ & $\begin{array}{c}\text { Tritium } \\
\text { (TU) }\end{array}$ & $\begin{array}{c}\Delta^{14} \mathrm{C} \\
(\%) \\
\end{array}$ \\
\hline \multicolumn{3}{|c|}{ Station 5: $16^{\circ} 35^{\prime} \mathrm{S} / 117^{\circ} 23^{\prime} \mathrm{E}$} & \multicolumn{3}{|c|}{ Station $8: 14^{\circ} 08^{\prime} \mathrm{S} / 116^{\circ} 42^{\prime} \mathrm{E}$} & \multicolumn{3}{|c|}{ Station 10: $12^{\circ} 31^{\prime} \mathrm{S} / 116^{\circ} 16^{\prime} \mathrm{E}$} \\
\hline 2.5 & - & 97 & 3.0 & 1.83 & 96 & 3.9 & 1.96 & 104 \\
\hline 29.5 & 1.69 & 102 & 28.8 & - & 118 & 28.8 & 1.76 & 102 \\
\hline 47.7 & 1.51 & 93 & 48.5 & 2.10 & 93 & 48.3 & 1.93 & 94 \\
\hline 67.3 & 1.95 & 79 & 69.3 & 1.98 & 84 & 67.2 & 1.90 & 84 \\
\hline 98.2 & 1.78 & 86 & 98.1 & 1.61 & 79 & 99.1 & 1.66 & 76 \\
\hline 150.0 & 1.88 & 56 & 148.5 & 1.66 & 80 & 148.6 & 1.65 & 26 \\
\hline 199.2 & 1.80 & 65 & 201.3 & 1.54 & 56 & 198.1 & 1.39 & 18 \\
\hline 298.8 & 1.24 & 3 & 298.0 & 1.33 & 11 & 298.8 & 1.01 & -33 \\
\hline 449.8 & 0.58 & -20 & 398.5 & 0.76 & -20 & 398.0 & 0.79 & -73 \\
\hline 499.7 & 0.42 & -58 & 600.4 & 0.24 & -119 & 601.3 & 0.34 & -116 \\
\hline 600.4 & 0.27 & -114 & 798.5 & 0.07 & -156 & 797.3 & 0.16 & -152 \\
\hline 798.0 & 0.19 & -162 & 998.4 & 0.08 & -161 & 998.0 & 0.07 & -173 \\
\hline 901.3 & 0.13 & -161 & 2001.6 & 0.001 & -200 & 1998.2 & 0.005 & -200 \\
\hline 997.7 & 0.09 & -173 & 4199.0 & 0.002 & -188 & 4193.8 & 0.001 & -187 \\
\hline \multicolumn{3}{|c|}{ Station $12: 11^{\circ} 23^{\prime} \mathrm{S} / 115^{\circ} 57^{\prime} \mathrm{E}$} & \multicolumn{3}{|c|}{ Station $16: 9^{\circ} 55^{\prime} \mathrm{S} / 115^{\circ} 32^{\prime} \mathrm{E}$} & \multicolumn{3}{|c|}{ Station 19: $9^{\circ} 14^{\prime} \mathrm{S} / 115^{\circ} 14^{\prime} \mathrm{E}$} \\
\hline 3.2 & - & 103 & 2.4 & 1.73 & 104 & - & - & - \\
\hline 28.2 & 1.82 & 111 & 29.9 & 1.83 & 90 & 25.9 & 1.98 & 68 \\
\hline 49.6 & 1.93 & 100 & 49.8 & 1.55 & 87 & 44.2 & 1.54 & 64 \\
\hline 68.0 & 1.57 & 111 & 68.2 & 1.74 & 77 & 66.4 & 1.65 & 66 \\
\hline 99.1 & 1.79 & 94 & 100.6 & 1.60 & 30 & 99.8 & 1.71 & 39 \\
\hline 125.2 & - & 70 & 149.6 & 1.43 & 11 & 150.1 & 0.89 & -61 \\
\hline 199.9 & - & 21 & 200.0 & 1.34 & 0 & 200.3 & 0.8 & -89 \\
\hline 299.2 & 0.95 & -46 & 301.6 & 0.96 & -54 & 299.9 & 0.59 & -91 \\
\hline 422.4 & 0.41 & -83 & 401.7 & 0.65 & -80 & 400.1 & 0.30 & -101 \\
\hline 500.4 & 0.27 & -112 & 604.5 & 0.23 & -128 & 499.8 & 0.22 & -122 \\
\hline 604.4 & 0.27 & -134 & 896.6 & 0.10 & -170 & 599.7 & 0.29 & -125 \\
\hline 798.8 & 0.10 & -152 & 1096.5 & 0.02 & -194 & 794.5 & - & -194 \\
\hline 906.2 & - & -153 & 1996.3 & 0.01 & -194 & 895.5 & - & -175 \\
\hline 997.4 & 0.07 & -173 & 3798.9 & 0.003 & -182 & 997.4 & - & -188 \\
\hline
\end{tabular}

upwelling that takes place along the coast of Bali clearly affects both tracer vertical distributions by bringing toward the surface waters from deeper levels, less tagged with ${ }^{14} \mathrm{C}$ and ${ }^{3} \mathrm{H}$. At deeper levels (below $1500 \mathrm{~m}$ ), ${ }^{3} \mathrm{H}$ concentrations drop below detection limit $(<0.01 \mathrm{TU})$, while ${ }^{14} \mathrm{C}$ concentrations reach their natural level, between -180 and $-200 \%$. The $\Delta{ }^{14} \mathrm{C}$ minimum at $2000 \mathrm{~m}$ depth is typical of the oldest waters in the Indian basin, whereas bottom waters, influenced by the more recently ventilated Antarctic Bottom Waters (AABW), display slightly higher values.

\section{Surface $\Delta^{14} \mathrm{C}$ and Origin of the Throughflow}

The $\Delta^{14} \mathrm{C}$ values in the mixed layer are in the range of $100-110 \%$, except at station 19 located off Bali $\left(\Delta^{14} \mathrm{C}=68 \%\right)$ which is influenced by the coastal upwelling. These surface $\Delta^{14} \mathrm{C}$ are in marked contrast with Indian Ocean data further west at the same latitude, which are in the range of 65-75\% (Figure 5). The spatial distribution of ${ }^{14} \mathrm{C}$ in the surface ocean, determined in the 1970 s thanks to the GEOSECS program, shows a strong gradient between middle latitudes and the $5^{\circ} \mathrm{S}-5^{\circ} \mathrm{N}$ belt, the 

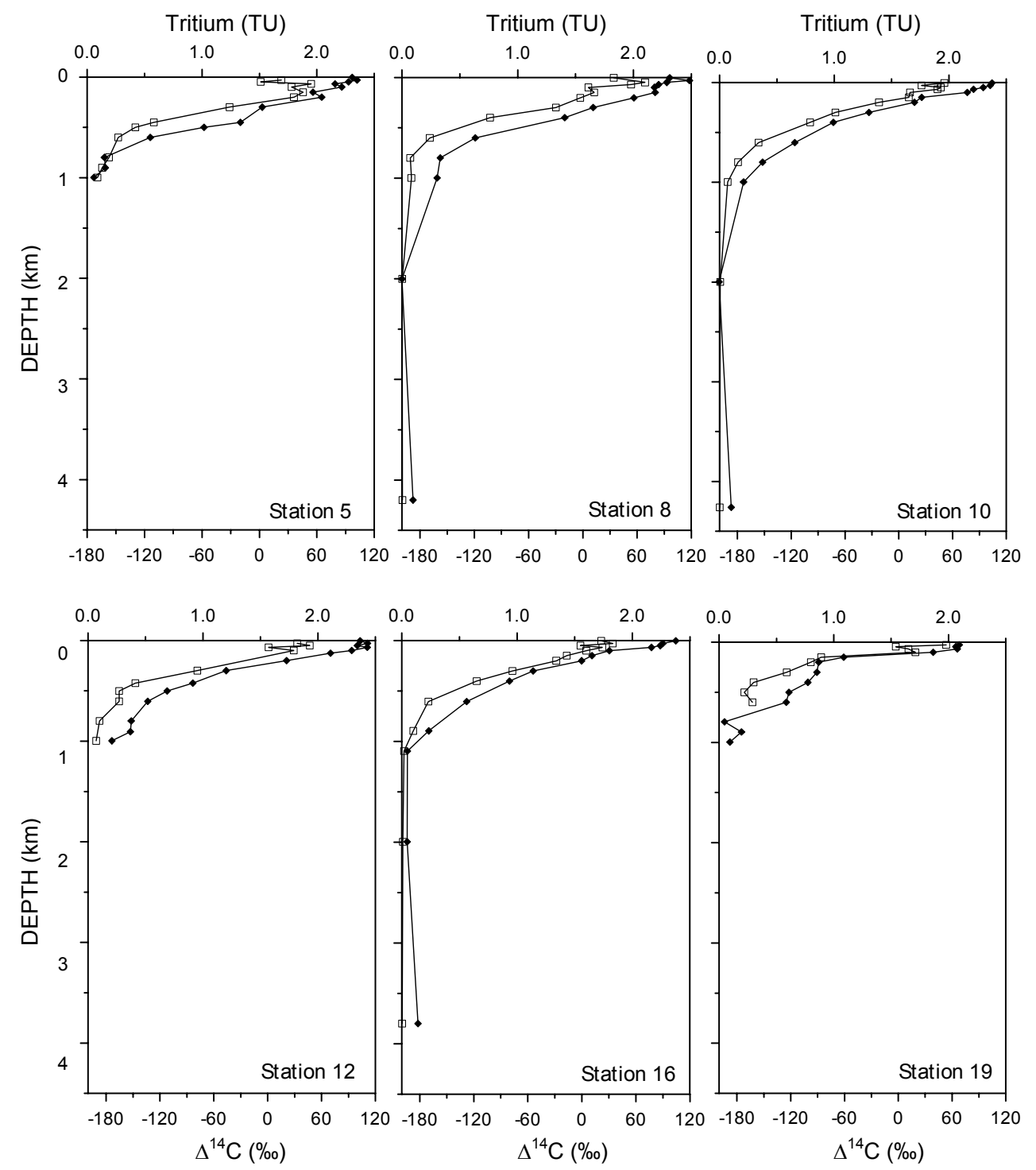

Figure 3 JADE-89 $\Delta{ }^{14} \mathrm{C}$ (black diamonds) and tritium (open squares) vertical profiles (stations 5, 8, 10, 12, 16, and 19).

$\Delta^{14} \mathrm{C}$ of which is lowered by the equatorial upwelling (Broecker et al. 1985). This latitudinal trend is still present in the WOCE data set (Figure 5), although not so strong, since the initial bomb signal is progressively smoothed by advection and mixing of the water masses. $\Delta^{14} \mathrm{C}$ surface values comparable to those observed along the JADE transect are found in the $10^{\circ} \mathrm{N}-15^{\circ} \mathrm{N}$ latitudinal belt of the Pacific Ocean, which corresponds to westward-flowing North Equatorial current (NEC).

Pacific waters that enter the Indonesian archipelago follow 2 different routes (Gordon and Fine 1996). The westernmost route, which is the main pathway, enters the Celebes Sea from the NEC-fed Mindanoa Current and proceeds through the Makassar Strait towards the Flores Sea before reaching the Banda Sea (Figure 1). The eastern route reaches the Banda Sea directly through the Halmahera and Molucca Seas. There, the waters from both routes mix before entering the Indian Ocean through 

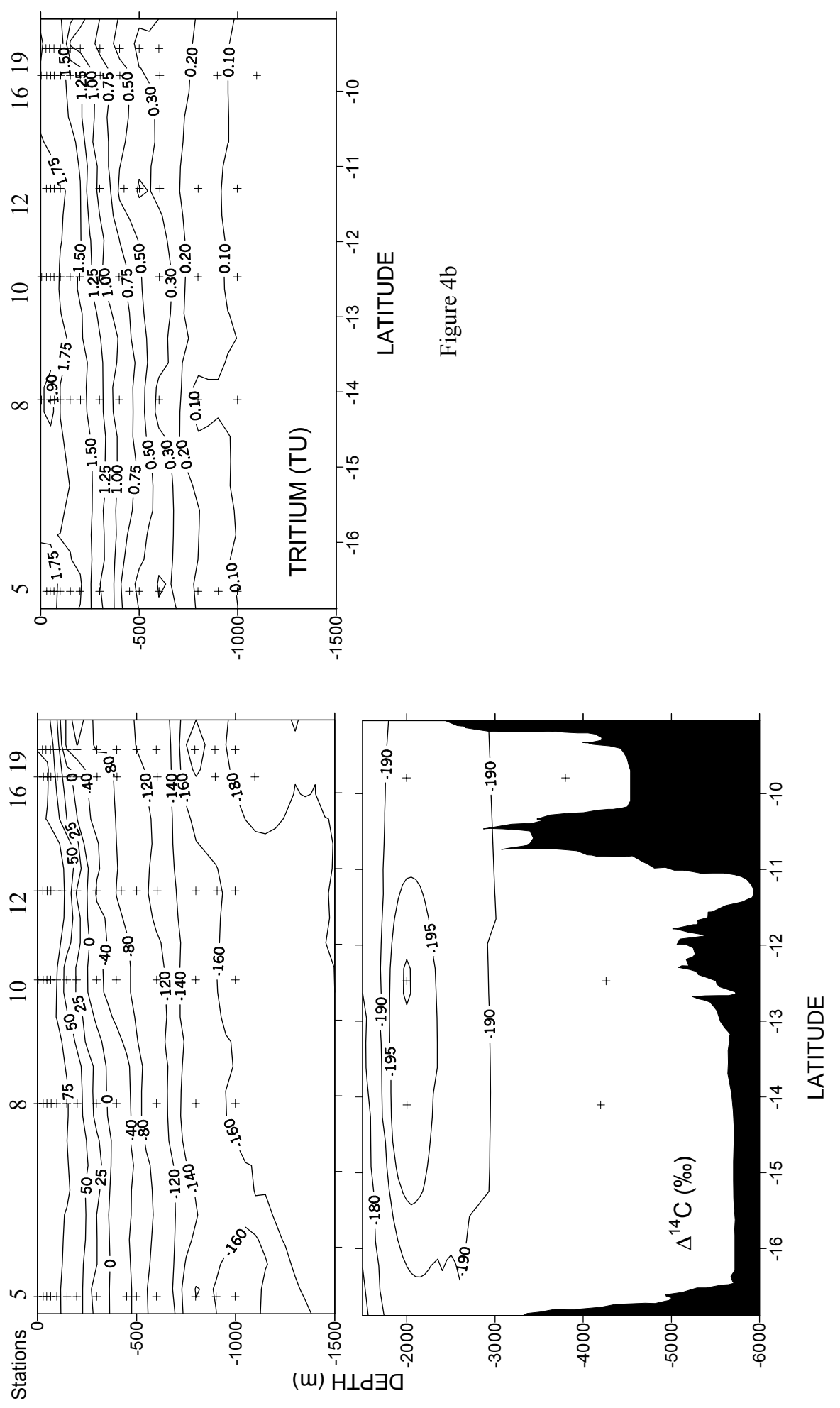

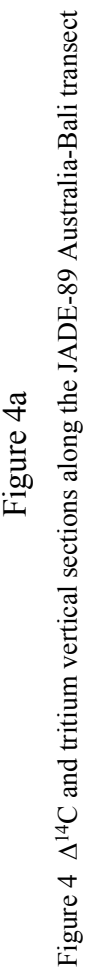




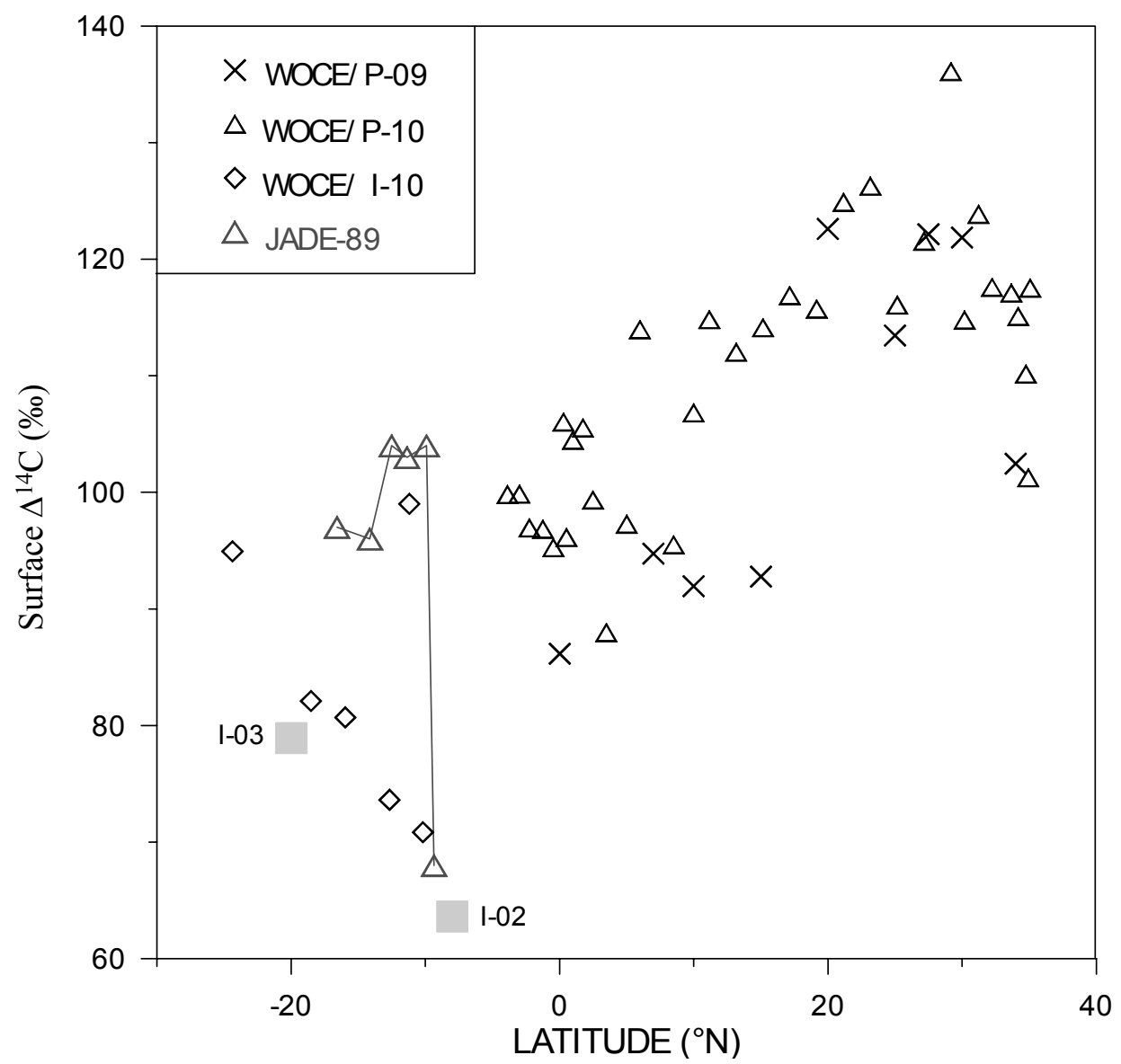

Figure 5 Plot of the WOCE (I-10, P-09, P-10) and JADE- $89 \Delta^{14} \mathrm{C}$ surface concentrations as a function of latitude (the grey squares represent the mean value of the 2 zonal sections I-02 and I-03).

the Savu and Timor Seas (Figure 1). By looking at the ${ }^{14} \mathrm{C}$ of corals from the Makassar Strait, Moore et al. (1997) have shown that their $\Delta^{14} \mathrm{C}$ are $60 \%$ higher than in corals from Canton Island, located in the Pacific South Equatorial Current (SEC), and identical to those of Guam, bathed by the NEC (lat. $13^{\circ} 30^{\prime} \mathrm{N}$ ). These findings strongly support the hydrographic observations (Fine 1985; Gordon 1986) which point to a northern Pacific origin of the waters following the western route. The origin of the waters taking the eastern route is less certain, with a possible contribution of the SEC (Field and Gordon 1992; Gordon and Fine 1996). The high $\Delta^{14} \mathrm{C}$ surface values measured along the JADE track do not favor any appreciable contribution of the South Pacific component to the waters crossing the Australia-Bali transect. However, the rather large scatter of the surface $\Delta^{14} \mathrm{C}$ from the WOCE western Pacific data set (Figure 5) prevent us to derive any precise figure concerning the upper limit of the South Pacific component. This scatter is due to the seasonal and interannual variability of the surface circulation and local upwellings, in relation to the various phases of the monsoon and to the ENSO phenomenon (Druffel 1987; Moore et al. 1997). 
Table 2 WOCE (I-02, I-03, I-10, P-09, P-10) and JADE-89 bomb ${ }^{14} \mathrm{C}$ inventories $\left(\Sigma^{14} \mathrm{C}_{\text {bomb }}\right.$ ), defined as $\Sigma^{14} \mathrm{C}_{\text {bomb }}=\left[\left(\Delta^{14} \mathrm{C}_{\text {total }}-\Delta^{14} \mathrm{C}_{\text {natural }}\right) \times \Delta \mathrm{z}\right]\left(\right.$ Unit: $\left.10^{3 \%} \% \times \mathrm{m}\right)$.

\begin{tabular}{|c|c|c|c|c|c|c|c|}
\hline Stations & Latitude & Longitude & $\Sigma^{14} \mathrm{C}_{\mathrm{bomb}}$ & Stations & Latitude & Longitude & $\Sigma^{14} \mathrm{C}_{\mathrm{bomb}}$ \\
\hline JADE-89 & & & & 1067 & $11^{\circ} 12^{\prime} \mathrm{S}$ & $108^{\circ} 55^{\prime} \mathrm{E}$ & 55.5 \\
\hline 5 & $16^{\circ} 35^{\prime} \mathrm{S}$ & $117^{\circ} 23^{\prime} \mathrm{E}$ & 61.8 & 1071 & $10^{\circ} 11^{\prime} \mathrm{S}$ & $107^{\circ} 17^{\prime} \mathrm{E}$ & 42.2 \\
\hline 8 & $14^{\circ} 08^{\prime} \mathrm{S}$ & $116^{\circ} 42^{\prime} \mathrm{E}$ & 64.7 & WOCE P-09 & & & \\
\hline 10 & $12^{\circ} 31^{\prime} \mathrm{S}$ & $116^{\circ} 16^{\prime} \mathrm{E}$ & 53.1 & 3 & $34^{\circ} 00^{\prime} \mathrm{N}$ & $136^{\circ} 59^{\prime} \mathrm{E}$ & 59.4 \\
\hline 12 & $11^{\circ} 23^{\prime} \mathrm{S}$ & $115^{\circ} 57^{\prime} \mathrm{E}$ & 53.1 & 21 & $30^{\circ} 00^{\prime} \mathrm{N}$ & $137^{\circ} 00^{\prime} \mathrm{E}$ & 136.3 \\
\hline 16 & $9^{\circ} 55^{\prime} \mathrm{S}$ & $115^{\circ} 32^{\prime} \mathrm{E}$ & 45.1 & 26 & $27^{\circ} 30^{\prime} \mathrm{N}$ & $137^{\circ} 00^{\prime} \mathrm{E}$ & 146.3 \\
\hline 19 & $9^{\circ} 14^{\prime} \mathrm{S}$ & $115^{\circ} 14^{\prime} \mathrm{E}$ & 32.2 & 31 & $25^{\circ} 00^{\prime} \mathrm{N}$ & $137^{\circ} 00^{\prime} \mathrm{E}$ & 114.5 \\
\hline WOCE I-02 & & & & 41 & $20^{\circ} 00^{\prime} \mathrm{N}$ & $137^{\circ} 01^{\prime} \mathrm{E}$ & 114.5 \\
\hline 1078 & $9^{\circ} 00^{\prime} \mathrm{S}$ & $105^{\circ} 38^{\prime} \mathrm{E}$ & 48.1 & 51 & $15^{\circ} 01^{\prime} \mathrm{N}$ & $137^{\circ} 00^{\prime} \mathrm{E}$ & 68.9 \\
\hline 1084 & $9^{\circ} 07^{\prime} \mathrm{S}$ & $102^{\circ} 00^{\prime} \mathrm{E}$ & 37.9 & 61 & $10^{\circ} 00^{\prime} \mathrm{N}$ & $137^{\circ} 00^{\prime} \mathrm{E}$ & 41.1 \\
\hline 1090 & $8^{\circ} 00^{\prime} \mathrm{S}$ & $98^{\circ} 00^{\prime} \mathrm{E}$ & 30.6 & 70 & $7^{\circ} 00^{\prime} \mathrm{N}$ & $137^{\circ} 00^{\prime} \mathrm{E}$ & 29.1 \\
\hline 1096 & $8^{\circ} 00^{\prime} \mathrm{S}$ & $94^{\circ} 00^{\prime} \mathrm{E}$ & 37.6 & 93 & $0^{\circ} 01^{\prime} \mathrm{N}$ & $142^{\circ} 00^{\prime} \mathrm{E}$ & 37.2 \\
\hline 1100 & $8^{\circ} 00^{\prime} \mathrm{S}$ & $91^{\circ} 20^{\prime} \mathrm{E}$ & 28.9 & WOCE P-10 & & & \\
\hline 1104 & $8^{\circ} 00^{\prime} \mathrm{S}$ & $89^{\circ} 22^{\prime} \mathrm{E}$ & 35.0 & 3 & $3^{\circ} 53^{\prime} \mathrm{S}$ & $144^{\circ} 54^{\prime} \mathrm{E}$ & 66.2 \\
\hline 1111 & $6^{\circ} 20^{\prime} \mathrm{S}$ & $88^{\circ} 25^{\prime} \mathrm{E}$ & 25.7 & 6 & $3^{\circ} 00^{\prime} \mathrm{S}$ & $145^{\circ} 17^{\prime} \mathrm{E}$ & 58.7 \\
\hline 1115 & $8^{\circ} 00^{\prime} \mathrm{S}$ & $88^{\circ} 00^{\prime} \mathrm{E}$ & 14.2 & 9 & $2^{\circ} 15^{\prime} \mathrm{S}$ & $145^{\circ} 30^{\prime} \mathrm{E}$ & 47.8 \\
\hline 1120 & $11^{\circ} 00^{\prime} \mathrm{S}$ & $88^{\circ} 02^{\prime} \mathrm{E}$ & 28.6 & 13 & $1^{\circ} 15^{\prime} \mathrm{S}$ & $145^{\circ} 47^{\prime} \mathrm{E}$ & 50.3 \\
\hline 1126 & $10^{\circ} 23^{\prime} \mathrm{S}$ & $88^{\circ} 25^{\prime} \mathrm{E}$ & 24.3 & 16 & $0^{\circ} 28^{\prime} \mathrm{S}$ & $146^{\circ} 00^{\prime} \mathrm{E}$ & 49.7 \\
\hline 1133 & $8^{\circ} 00^{\prime} \mathrm{S}$ & $83^{\circ} 20^{\prime} \mathrm{E}$ & 57.8 & 18 & $0^{\circ} 17^{\prime} \mathrm{N}$ & $146^{\circ} 09^{\prime} \mathrm{E}$ & 54.7 \\
\hline 1143 & $8^{\circ} 00^{\prime} \mathrm{S}$ & $76^{\circ} 40^{\prime} \mathrm{E}$ & 44.3 & 20 & $0^{\circ} 30^{\prime} \mathrm{N}$ & $146^{\circ} 17^{\prime} \mathrm{E}$ & 56.3 \\
\hline 1150 & $8^{\circ} 00^{\prime} \mathrm{S}$ & $72^{\circ} 49^{\prime} \mathrm{E}$ & 43.0 & 22 & $1^{\circ} 00^{\prime} \mathrm{N}$ & $146^{\circ} 26^{\prime} \mathrm{E}$ & 48.8 \\
\hline 1155 & $8^{\circ} 00^{\prime} \mathrm{S}$ & $71^{\circ} 02^{\prime} \mathrm{E}$ & 49.2 & 25 & $1^{\circ} 45^{\prime} \mathrm{N}$ & $146^{\circ} 39^{\prime} \mathrm{E}$ & 54.3 \\
\hline WOCE I-03 & & & & 28 & $2^{\circ} 30^{\prime} \mathrm{N}$ & $146^{\circ} 52^{\prime} \mathrm{E}$ & 50.0 \\
\hline 449 & $22^{\circ} 04^{\prime} \mathrm{S}$ & $112^{\circ} 49^{\prime} \mathrm{E}$ & 82.0 & 31 & $3^{\circ} 29^{\prime} \mathrm{N}$ & $147^{\circ} 14^{\prime} \mathrm{E}$ & 38.1 \\
\hline 452 & $21^{\circ} 40^{\prime} \mathrm{S}$ & $111^{\circ} 22^{\prime} \mathrm{E}$ & 76.7 & 34 & $5^{\circ} 00^{\prime} \mathrm{N}$ & $147^{\circ} 51^{\prime} \mathrm{E}$ & 37.5 \\
\hline 455 & $20^{\circ} 50^{\prime} \mathrm{S}$ & $109^{\circ} 26^{\prime} \mathrm{E}$ & 70.4 & 36 & $6^{\circ} 00^{\prime} \mathrm{N}$ & $148^{\circ} 17^{\prime} \mathrm{E}$ & 39.6 \\
\hline 461 & $20^{\circ} 00^{\prime} \mathrm{S}$ & $104^{\circ} 53^{\prime} \mathrm{E}$ & 68.8 & 41 & $8^{\circ} 30^{\prime} \mathrm{N}$ & $149^{\circ} 20^{\prime} \mathrm{E}$ & 32.3 \\
\hline 465 & $20^{\circ} 00^{\prime} \mathrm{S}$ & $101^{\circ} 21^{\prime} \mathrm{E}$ & 94.6 & 45 & $10^{\circ} 00^{\prime} \mathrm{N}$ & $149^{\circ} 20^{\prime} \mathrm{E}$ & 39.4 \\
\hline 469 & $20^{\circ} 00^{\prime} \mathrm{S}$ & $97^{\circ} 50^{\prime} \mathrm{E}$ & 93.9 & 47 & $11^{\circ} 10^{\prime} \mathrm{N}$ & $149^{\circ} 20^{\prime} \mathrm{E}$ & 44.1 \\
\hline 476 & $20^{\circ} 00^{\prime} \mathrm{S}$ & $92^{\circ} 21^{\prime} \mathrm{E}$ & 97.0 & 50 & $13^{\circ} 10^{\prime} \mathrm{N}$ & $149^{\circ} 20^{\prime} \mathrm{E}$ & 59.4 \\
\hline 483 & $20^{\circ} 00^{\prime} \mathrm{S}$ & $89^{\circ} 28^{\prime} \mathrm{E}$ & 100.5 & 53 & $15^{\circ} 10^{\prime} \mathrm{N}$ & $149^{\circ} 20^{\prime} \mathrm{E}$ & 69.0 \\
\hline 491 & $20^{\circ} 00^{\prime} \mathrm{S}$ & $85^{\circ} 18^{\prime} \mathrm{E}$ & 105.0 & 56 & $17^{\circ} 10^{\prime} \mathrm{N}$ & $149^{\circ} 20^{\prime} \mathrm{E}$ & 77.6 \\
\hline 495 & $20^{\circ} 00^{\prime} \mathrm{S}$ & $82^{\circ} 44^{\prime} \mathrm{E}$ & 111.4 & 59 & $19^{\circ} 10^{\prime} \mathrm{N}$ & $149^{\circ} 20^{\prime} \mathrm{E}$ & 93.9 \\
\hline 501 & $20^{\circ} 00^{\prime} \mathrm{S}$ & $78^{\circ} 21^{\prime} \mathrm{E}$ & 100.7 & 62 & $21^{\circ} 10^{\prime} \mathrm{N}$ & $149^{\circ} 20^{\prime} \mathrm{E}$ & 115.1 \\
\hline 505 & $20^{\circ} 00^{\prime} \mathrm{S}$ & $75^{\circ} 27^{\prime} \mathrm{E}$ & 106.0 & 65 & $23^{\circ} 10^{\prime} \mathrm{N}$ & $149^{\circ} 20^{\prime} \mathrm{E}$ & 118.1 \\
\hline 507 & $20^{\circ} 00^{\prime} \mathrm{S}$ & $74^{\circ} 10^{\prime} \mathrm{E}$ & 101.2 & 68 & $25^{\circ} 10^{\prime} \mathrm{N}$ & $149^{\circ} 20^{\prime} \mathrm{E}$ & 112.9 \\
\hline 512 & $20^{\circ} 00^{\prime} \mathrm{S}$ & $71^{\circ} 42^{\prime} \mathrm{E}$ & 101.4 & 71 & $27^{\circ} 10^{\prime} \mathrm{N}$ & $149^{\circ} 20^{\prime} \mathrm{E}$ & 117.4 \\
\hline 517 & $20^{\circ} 00^{\prime} \mathrm{S}$ & $69^{\circ} 22^{\prime} \mathrm{E}$ & 113.2 & 74 & $29^{\circ} 10^{\prime} \mathrm{N}$ & $149^{\circ} 20^{\prime} \mathrm{E}$ & 124.2 \\
\hline 526 & $20^{\circ} 11^{\prime} \mathrm{S}$ & $64^{\circ} 25^{\prime} \mathrm{E}$ & 115.2 & 76 & $30^{\circ} 11^{\prime} \mathrm{N}$ & $148^{\circ} 03^{\prime} \mathrm{E}$ & 139.5 \\
\hline 531 & $20^{\circ} 22^{\prime} \mathrm{S}$ & $61^{\circ} 38^{\prime} \mathrm{E}$ & 117.0 & 78 & $31^{\circ} 13^{\prime} \mathrm{N}$ & $146^{\circ} 46^{\prime} \mathrm{E}$ & 138.1 \\
\hline 535 & $20^{\circ} 22^{\prime} \mathrm{S}$ & $59^{\circ} 13^{\prime} \mathrm{E}$ & 113.8 & 80 & $32^{\circ} 14^{\prime} \mathrm{N}$ & $145^{\circ} 28^{\prime} \mathrm{E}$ & 140.6 \\
\hline 550 & $20^{\circ} 00^{\prime} \mathrm{S}$ & $53^{\circ} 20^{\prime} \mathrm{E}$ & 103.5 & 83 & $33^{\circ} 40^{\prime} \mathrm{N}$ & $143^{\circ} 40^{\prime} \mathrm{E}$ & 142.6 \\
\hline 557 & $20^{\circ} 00^{\prime} \mathrm{S}$ & $50^{\circ} 04^{\prime} \mathrm{E}$ & 84.3 & 85 & $34^{\circ} 11^{\prime} \mathrm{N}$ & $142^{\circ} 43^{\prime} \mathrm{E}$ & 134.2 \\
\hline WOCE I-10 & & & & 88 & $34^{\circ} 45^{\prime} \mathrm{N}$ & $141^{\circ} 39^{\prime} \mathrm{E}$ & 77.2 \\
\hline 1015 & $24^{\circ} 23^{\prime} \mathrm{S}$ & $110^{\circ} 35^{\prime} \mathrm{E}$ & 112.9 & 90 & $34^{\circ} 56^{\prime} \mathrm{N}$ & $141^{\circ} 12^{\prime} \mathrm{E}$ & 56.1 \\
\hline 1045 & $18^{\circ} 32^{\prime} \mathrm{S}$ & $111^{\circ} 05^{\prime} \mathrm{E}$ & 89.7 & 92 & $35^{\circ} 05^{\prime} \mathrm{N}$ & $140^{\circ} 54^{\prime} \mathrm{E}$ & 66.8 \\
\hline 1051 & $15^{\circ} 58^{\prime} \mathrm{S}$ & $111^{\circ} 18^{\prime} \mathrm{E}$ & 80.4 & & & & \\
\hline 1059 & $12^{\circ} 41^{\prime} \mathrm{S}$ & $111^{\circ} 35^{\prime} \mathrm{E}$ & 52.4 & & & & \\
\hline
\end{tabular}




\section{${ }^{14} \mathrm{C}$ Water Column Inventories}

${ }^{14} \mathrm{C}$ inventories are indicated in Table 2 . The inventory of bomb ${ }^{14} \mathrm{C}$ at a given location is the amount of ${ }^{14} \mathrm{C}$ in excess of the natural prebomb concentrations. It is obtained by subtracting the natural ${ }^{14} \mathrm{C}$ component from the total ${ }^{14} \mathrm{C}$ water column inventory. We calculated the natural component using the classic empirical formula of Broecker et al. (1995), which links the natural $\Delta^{14} \mathrm{C}$ to the dissolved silica concentration $\left(\mathrm{SiO}_{2}\right)$ :

$$
\Delta^{14} \mathrm{C} \%{ }_{0}=-70 \%{ }_{0}-\mathrm{SiO}_{2},
$$

where silica concentrations are expressed in $\mu \mathrm{mol} / \mathrm{kg}$ (as alkalinity-based estimates are not available for the JADE cruise, this method was preferred to the Palk method of Rubin and Key [2002] for the sake of consistency).

The bomb ${ }^{14} \mathrm{C}$ inventories are plotted as a function of latitude in Figure 6a. Geographical patterns of the bomb ${ }^{14} \mathrm{C}$ inventory at the scale of the main ocean basin reflect the spatial distribution of the surface $\Delta^{14} \mathrm{C}$; however, it is also strongly affected by the spatial pattern of the penetration depth of the tracer. Systematic latitudinal variations were first revealed by the GEOSECS program, with subtropical maxima in both hemispheres and an equatorial minimum (Broecker et al. 1985). This latitudinal pattern is the consequence of the input function structure of oceanic ${ }^{14} \mathrm{C}$, determined by the exchange of ${ }^{14} \mathrm{CO}_{2}$ at the air-sea interface, and of the large-scale redistribution of the tracer by the ocean circulation (Toggweiler et al. 1989). This latitudinal trend is also apparent in the WOCE data set (Figure 6a). However, as far as the origin of the throughflow waters is concerned, Figure 6a shows that both the NEC and SEC display bomb ${ }^{14} \mathrm{C}$ inventories in the same range. Therefore, ${ }^{14} \mathrm{C}$ inventories do not permit to discriminate between the 2 sources.

\section{Tritium Water Column Inventories}

The tritium inventories at the JADE stations and at the WOCE stations on both sides of the ITF are summarized in Table 3. In order to remove the influence of the radioactive decay, which is significant even over short periods of time due to the relatively short tritium half-life of $12.4 \mathrm{yr}$, all the inventories were decay-corrected to 1 January 1991 (notation TU 91). The geographical pattern of the tritium inventories is characterized by a large contrast between the 2 hemispheres (Broecker et al. 1986b). This is due to the fact that most bomb atmospheric detonations and subsequent tritium fallout occurred in the Northern Hemisphere and to the short residence time of water in the atmosphere (Weiss and Roether 1980). The maximum tritium delivery is observed at middle latitudes. In Figure $6 \mathrm{~b}$, the plot of the tritium inventories as a function of latitude reveals that the JADE data points are well above the values typical of the SEC, again strongly suggesting a northern Pacific origin of the waters.

\section{DISCUSSION}

The average tritium inventory along the JADE transect (excluding station 19 next to the coast of Bali because of the perturbation by the upwelling) is about $25 \%$ below the North Pacific endmember, which is in the range 780-1080 TU91 $\times$ m (Figure 6b). A priori, this $25 \%$ change can be due to some mixing with the low-tritium South Pacific component, or simply to the aging of the North Pacific waters during their transit across the Indonesian archipelago, or to a combination of both processes. In Figure 7, the diagram representing the surface $\Delta^{14} \mathrm{C}$ against tritium inventories suggests that the JADE domain is best explained by a simple aging process of the NEC waters, with no significant contribution from the SEC component. 

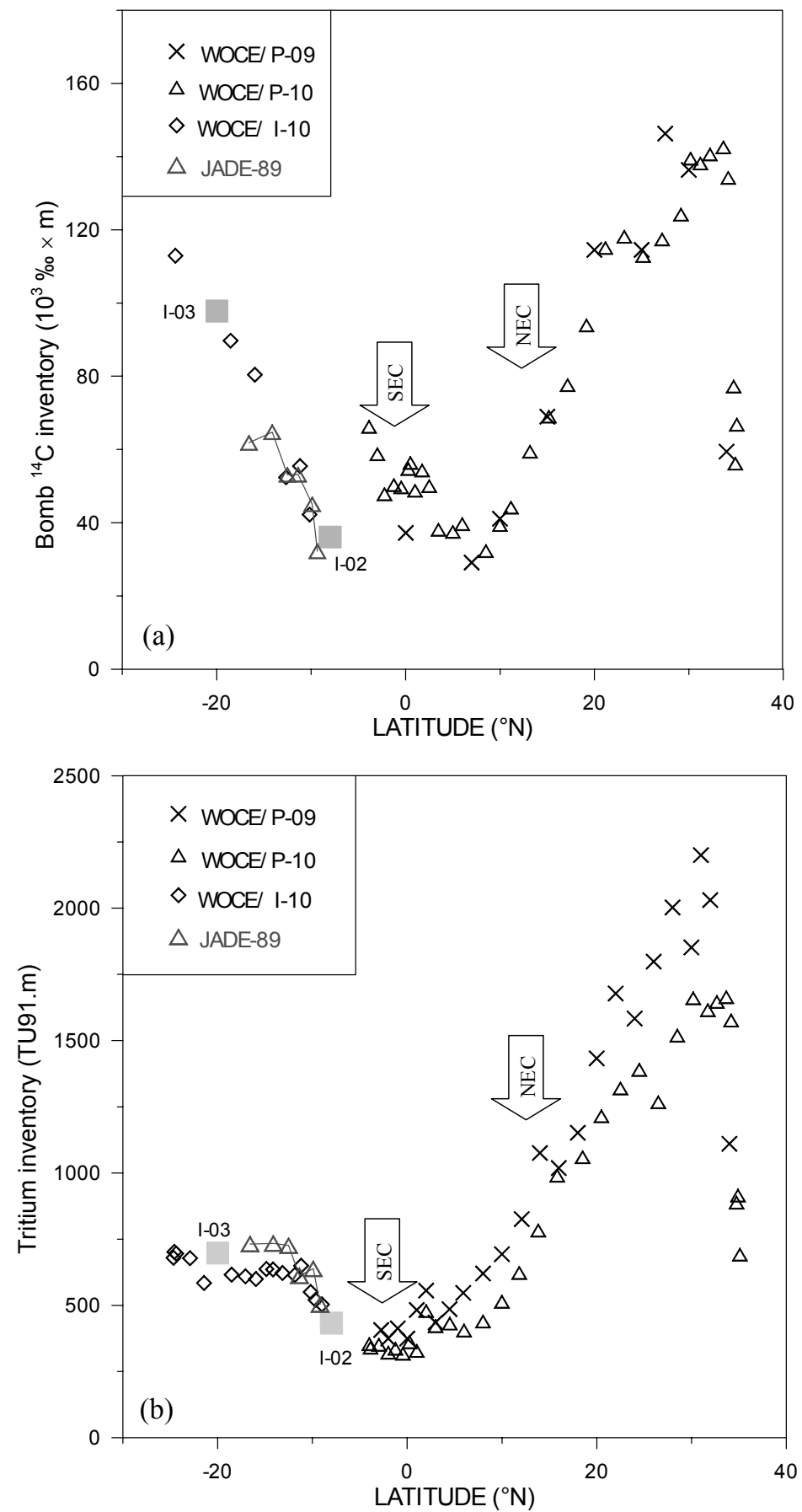

Figure 6 Plot of the WOCE and JADE- 89 bomb ${ }^{14} \mathrm{C}$ (a) and tritium (b) inventories as a function of latitude (the grey squares represent the mean value of the 2 zonal sections I-02 and I-03). The 2 arrows signal the core of the NEC when approaching the bifurcation at the Philippines coast (Toole et al. 1990) and the branch of the SEC materialized at this latitude by the New Guinea Coastal Current (Fine et al. 1994). 
Table 3 WOCE (I-02, I-03, I-10, P-09, P-10) and JADE-89 tritium inventories $\left(\Sigma^{3} \mathrm{H}_{91}\right)$, decay-corrected to 1 January 1991 (Unit: TU91 $\times$ m).

\begin{tabular}{|c|c|c|c|c|c|c|c|}
\hline Stations & Latitude & Longitude & $\Sigma^{3} \mathrm{H}_{91}$ & Stations & Latitude & Longitude & $\Sigma^{3} \mathrm{H}_{91}$ \\
\hline JADE-89 & & & & 1039 & $21^{\circ} 27^{\prime} \mathrm{E}$ & $110^{\circ} 50^{\prime} \mathrm{E}$ & 584.0 \\
\hline 5 & $16^{\circ} 35^{\prime} \mathrm{S}$ & $117^{\circ} 23^{\prime} \mathrm{E}$ & 731.9 & 1045 & $18^{\circ} 32^{\prime} \mathrm{E}$ & $111^{\circ} 05^{\prime} \mathrm{E}$ & 615.6 \\
\hline 8 & $14^{\circ} 08^{\prime} \mathrm{S}$ & $116^{\circ} 42^{\prime} \mathrm{E}$ & 733.8 & 1048 & $17^{\circ} 04^{\prime} \mathrm{E}$ & $111^{\circ} 13^{\prime} \mathrm{E}$ & 609.1 \\
\hline 10 & $12^{\circ} 31^{\prime} \mathrm{S}$ & $116^{\circ} 16^{\prime} \mathrm{E}$ & 725.6 & 1051 & $15^{\circ} 58^{\prime} \mathrm{E}$ & $111^{\circ} 18^{\prime} \mathrm{E}$ & 599.1 \\
\hline 12 & $11^{\circ} 23^{\prime} \mathrm{S}$ & $115^{\circ} 57^{\prime} \mathrm{E}$ & 611.7 & 1054 & $14^{\circ} 52^{\prime} \mathrm{E}$ & $111^{\circ} 24^{\prime} \mathrm{E}$ & 637.4 \\
\hline 16 & $9^{\circ} 55^{\prime} \mathrm{S}$ & $115^{\circ} 32^{\prime} \mathrm{E}$ & 638.1 & 1056 & $14^{\circ} 09^{\prime} \mathrm{E}$ & $111^{\circ} 27^{\prime} \mathrm{E}$ & 635.1 \\
\hline 19 & $9^{\circ} 14^{\prime} \mathrm{S}$ & $115^{\circ} 14^{\prime} \mathrm{E}$ & 503.6 & 1058 & $13^{\circ} 10^{\prime} \mathrm{E}$ & $111^{\circ} 32^{\prime} \mathrm{E}$ & 621.8 \\
\hline WOCE I-02 & & & & 1062 & $11^{\circ} 52^{\prime} \mathrm{E}$ & $111^{\circ} 22^{\prime} \mathrm{E}$ & 614.3 \\
\hline 1078 & $9^{\circ} 00^{\prime} \mathrm{S}$ & $105^{\circ} 38^{\prime} \mathrm{E}$ & 514.3 & 1067 & $11^{\circ} 12^{\prime} \mathrm{E}$ & $108^{\circ} 55^{\prime} \mathrm{E}$ & 649.2 \\
\hline 1079 & $9^{\circ} 07^{\prime} \mathrm{S}$ & $105^{\circ} 10^{\prime} \mathrm{E}$ & 448.8 & 1071 & $10^{\circ} 11^{\prime} \mathrm{E}$ & $107^{\circ} 17^{\prime} \mathrm{E}$ & 550.2 \\
\hline 1081 & $9^{\circ} 07^{\prime} \mathrm{S}$ & $104^{\circ} 00^{\prime} \mathrm{E}$ & 472.6 & 1073 & $9^{\circ} 40^{\prime} \mathrm{E}$ & $106^{\circ} 27^{\prime} \mathrm{E}$ & 520.2 \\
\hline 1087 & $8^{\circ} 34^{\prime} \mathrm{S}$ & $100^{\circ} 00^{\prime} \mathrm{E}$ & 436.8 & 1075 & $9^{\circ} 00^{\prime} \mathrm{E}$ & $105^{\circ} 38^{\prime} \mathrm{E}$ & 502.5 \\
\hline 1094 & $8^{\circ} 00^{\prime} \mathrm{S}$ & $95^{\circ} 20^{\prime} \mathrm{E}$ & 372.7 & WOCE P-09 & & & \\
\hline 1102 & $8^{\circ} 00^{\prime} \mathrm{S}$ & $90^{\circ} 00^{\prime} \mathrm{E}$ & 364.7 & 3 & $34^{\circ} 00^{\prime} \mathrm{N}$ & $136^{\circ} 59^{\prime} \mathrm{E}$ & 1110.4 \\
\hline 1106 & $6^{\circ} 00^{\prime} \mathrm{S}$ & $88^{\circ} 29^{\prime} \mathrm{E}$ & 357.6 & 15 & $31^{\circ} 59^{\prime} \mathrm{N}$ & $137^{\circ} 00^{\prime} \mathrm{E}$ & 2031.1 \\
\hline 1110 & $5^{\circ} 31^{\prime} \mathrm{S}$ & $88^{\circ} 30^{\prime} \mathrm{E}$ & 352.6 & 18 & $31^{\circ} 00^{\prime} \mathrm{N}$ & $137^{\circ} 00^{\prime} \mathrm{E}$ & 2200.6 \\
\hline 1116 & $10^{\circ} 02^{\prime} \mathrm{S}$ & $88^{\circ} 00^{\prime} \mathrm{E}$ & 548.5 & 21 & $30^{\circ} 00^{\prime} \mathrm{N}$ & $137^{\circ} 00^{\prime} \mathrm{E}$ & 1851.5 \\
\hline 1120 & $11^{\circ} 00^{\prime} \mathrm{S}$ & $88^{\circ} 02^{\prime} \mathrm{E}$ & 585.1 & 25 & $28^{\circ} 00^{\prime} \mathrm{N}$ & $137^{\circ} 00^{\prime} \mathrm{E}$ & 2002.6 \\
\hline 1130 & $8^{\circ} 00^{\prime} \mathrm{S}$ & $85^{\circ} 20^{\prime} \mathrm{E}$ & 395.7 & 29 & $26^{\circ} 00^{\prime} \mathrm{N}$ & $137^{\circ} 00^{\prime} \mathrm{E}$ & 1798.0 \\
\hline 1138 & $8^{\circ} 00^{\prime} \mathrm{S}$ & $80^{\circ} 00^{\prime} \mathrm{E}$ & 399.8 & 33 & $24^{\circ} 00^{\prime} \mathrm{N}$ & $137^{\circ} 00^{\prime} \mathrm{E}$ & 1583.3 \\
\hline \multirow{2}{*}{1145} & $8^{\circ} 00^{\prime} \mathrm{S}$ & $75^{\circ} 20^{\prime} \mathrm{E}$ & 373.5 & 37 & $22^{\circ} 00^{\prime} \mathrm{N}$ & $137^{\circ} 24^{\prime} \mathrm{E}$ & 1677.9 \\
\hline & & & & 41 & $20^{\circ} 00^{\prime} \mathrm{N}$ & $137^{\circ} 00^{\prime} \mathrm{E}$ & 1432.6 \\
\hline WOCE I-03 & & & & 45 & $18^{\circ} 00^{\prime} \mathrm{N}$ & $137^{\circ} 00^{\prime} \mathrm{E}$ & 1151.5 \\
\hline 445 & $22^{\circ} 13^{\prime} \mathrm{S}$ & $113^{\circ} 42^{\prime} \mathrm{E}$ & 638.2 & 49 & $16^{\circ} 00^{\prime} \mathrm{N}$ & $136^{\circ} 58^{\prime} \mathrm{E}$ & 1018.1 \\
\hline 446 & $22^{\circ} 12^{\prime} \mathrm{S}$ & $113^{\circ} 36^{\prime} \mathrm{E}$ & 638.1 & 53 & $14^{\circ} 00^{\prime} \mathrm{N}$ & $137^{\circ} 00^{\prime} \mathrm{E}$ & 1075.2 \\
\hline 448 & $22^{\circ} 08^{\prime} \mathrm{S}$ & $113^{\circ} 10^{\prime} \mathrm{E}$ & 649.4 & 57 & $12^{\circ} 05^{\prime} \mathrm{N}$ & $137^{\circ} 00^{\prime} \mathrm{E}$ & 825.7 \\
\hline 449 & $22^{\circ} 05^{\prime} \mathrm{S}$ & $112^{\circ} 49^{\prime} \mathrm{E}$ & 645.8 & 61 & $10^{\circ} 00^{\prime} \mathrm{N}$ & $137^{\circ} 00^{\prime} \mathrm{E}$ & 692.9 \\
\hline 451 & $21^{\circ} 50^{\prime} \mathrm{S}$ & $111^{\circ} 54^{\prime} \mathrm{E}$ & 615.9 & 66 & $8^{\circ} 00^{\prime} \mathrm{N}$ & $137^{\circ} 00^{\prime} \mathrm{E}$ & 620.3 \\
\hline 454 & $21^{\circ} 09^{\prime} \mathrm{S}$ & $110^{\circ} 09^{\prime} \mathrm{E}$ & 668.6 & 73 & $5^{\circ} 55^{\prime} \mathrm{N}$ & $138^{\circ} 04^{\prime} \mathrm{E}$ & 547.0 \\
\hline 459 & $20^{\circ} 00^{\prime} \mathrm{S}$ & $106^{\circ} 37^{\prime} \mathrm{E}$ & 622.1 & 77 & $4^{\circ} 28^{\prime} \mathrm{N}$ & $139^{\circ} 35^{\prime} \mathrm{E}$ & 485.6 \\
\hline 464 & $20^{\circ} 00^{\prime} \mathrm{S}$ & $102^{\circ} 14^{\prime} \mathrm{E}$ & 643.9 & 81 & $3^{\circ} 01^{\prime} \mathrm{N}$ & $141^{\circ} 07^{\prime} \mathrm{E}$ & 435.4 \\
\hline 469 & $20^{\circ} 00^{\prime} \mathrm{S}$ & $97^{\circ} 50^{\prime} \mathrm{E}$ & 686.4 & 85 & $2^{\circ} 02^{\prime} \mathrm{N}$ & $142^{\circ} 03^{\prime} \mathrm{E}$ & 555.7 \\
\hline 480 & $20^{\circ} 00^{\prime} \mathrm{S}$ & $90^{\circ} 17^{\prime} \mathrm{E}$ & 708.8 & 89 & $1^{\circ} 01^{\prime} \mathrm{N}$ & $142^{\circ} 00^{\prime} \mathrm{E}$ & 482.4 \\
\hline 490 & $20^{\circ} 00^{\prime} \mathrm{S}$ & $85^{\circ} 56^{\prime} \mathrm{E}$ & 703.8 & 93 & $0^{\circ} 00^{\prime} \mathrm{N}$ & $142^{\circ} 00^{\prime} \mathrm{E}$ & 374.4 \\
\hline 496 & $20^{\circ} 00^{\prime} \mathrm{S}$ & $82^{\circ} 00^{\prime} \mathrm{E}$ & 717.8 & 97 & $1^{\circ} 00^{\prime} \mathrm{S}$ & $142^{\circ} 02^{\prime} \mathrm{E}$ & 413.0 \\
\hline 501 & $20^{\circ} 00^{\prime} \mathrm{S}$ & $78^{\circ} 22^{\prime} \mathrm{E}$ & 728.4 & 101 & $2^{\circ} 00^{\prime} \mathrm{S}$ & $142^{\circ} 00^{\prime} \mathrm{E}$ & 374.8 \\
\hline 507 & $20^{\circ} 00^{\prime} \mathrm{S}$ & $74^{\circ} 10^{\prime} \mathrm{E}$ & 718.2 & 104 & $2^{\circ} 45^{\prime} \mathrm{S}$ & $142^{\circ} 15^{\prime} \mathrm{E}$ & 406.8 \\
\hline 515 & $20^{\circ} 00^{\prime} \mathrm{S}$ & $70^{\circ} 15^{\prime} \mathrm{E}$ & 744.2 & WOCE P-10 & & & \\
\hline 523 & $20^{\circ} 00^{\prime} \mathrm{S}$ & $65^{\circ} 59^{\prime} \mathrm{E}$ & 739.5 & 1 & $4^{\circ} 01^{\prime} \mathrm{S}$ & $144^{\circ} 49^{\prime} \mathrm{E}$ & 353.8 \\
\hline 530 & $20^{\circ} 22^{\prime} \mathrm{S}$ & $62^{\circ} 15^{\prime} \mathrm{E}$ & 784.0 & 3 & $3^{\circ} 53^{\prime} \mathrm{S}$ & $144^{\circ} 53^{\prime} \mathrm{E}$ & 340.1 \\
\hline 537 & $20^{\circ} 22^{\prime} \mathrm{S}$ & $58^{\circ} 09^{\prime} \mathrm{E}$ & 789.4 & 6 & $3^{\circ} 00^{\prime} \mathrm{S}$ & $145^{\circ} 17^{\prime} \mathrm{E}$ & 351.4 \\
\hline 549 & $20^{\circ} 00^{\prime} \mathrm{S}$ & $53^{\circ} 53^{\prime} \mathrm{E}$ & 764.2 & 10 & $2^{\circ} 00^{\prime} \mathrm{S}$ & $145^{\circ} 34^{\prime} \mathrm{E}$ & 321.6 \\
\hline 554 & $20^{\circ} 00^{\prime} \mathrm{S}$ & $51^{\circ} 18^{\prime} \mathrm{E}$ & 762.1 & 13 & $1^{\circ} 15^{\prime} \mathrm{S}$ & $145^{\circ} 47^{\prime} \mathrm{E}$ & 336.5 \\
\hline 557 & $20^{\circ} 00^{\prime} \mathrm{S}$ & $50^{\circ} 04^{\prime} \mathrm{E}$ & 673.8 & 16 & $0^{\circ} 28^{\prime} \mathrm{S}$ & $146^{\circ} 00^{\prime} \mathrm{E}$ & 317.8 \\
\hline WOCE I-10 & & & & 19 & $0^{\circ} 15^{\prime} \mathrm{S}$ & $146^{\circ} 13^{\prime} \mathrm{E}$ & 360.9 \\
\hline 1015 & $24^{\circ} 23^{\prime} \mathrm{S}$ & $110^{\circ} 35^{\prime} \mathrm{E}$ & 695.6 & 22 & $1^{\circ} 00^{\prime} \mathrm{N}$ & $146^{\circ} 26^{\prime} \mathrm{E}$ & 328.2 \\
\hline 1020 & $24^{\circ} 40^{\prime} \mathrm{S}$ & $112^{\circ} 12^{\prime} \mathrm{E}$ & 679.6 & 26 & $2^{\circ} 00^{\prime} \mathrm{N}$ & $146^{\circ} 43^{\prime} \mathrm{E}$ & 479.0 \\
\hline 1030 & $24^{\circ} 34^{\prime} \mathrm{S}$ & $111^{\circ} 39^{\prime} \mathrm{E}$ & 701.9 & 30 & $3^{\circ} 00^{\prime} \mathrm{N}$ & $147^{\circ} 00^{\prime} \mathrm{E}$ & 421.4 \\
\hline 1036 & $22^{\circ} 55^{\prime} \mathrm{S}$ & $110^{\circ} 43^{\prime} \mathrm{E}$ & 678.0 & 33 & $4^{\circ} 30^{\prime} \mathrm{N}$ & $147^{\circ} 39^{\prime} \mathrm{E}$ & 431.3 \\
\hline
\end{tabular}


Table 3 WOCE (I-02, I-03, I-10, P-09, P-10) and JADE-89 tritium inventories $\left(\Sigma^{3} \mathrm{H}_{91}\right)$, decay-corrected to 1 January 1991 (Unit: TU91×m). (Continued)

\begin{tabular}{lrlr|llll}
\hline Stations & Latitude & Longitude & $\Sigma^{3} \mathrm{H}_{91}$ & Stations & Latitude & Longitude & $\Sigma^{3} \mathrm{H}_{91}$ \\
\hline WOCE P-10 & & & & 67 & $24^{\circ} 30^{\prime} \mathrm{N}$ & $149^{\circ} 20^{\prime} \mathrm{E}$ & 1390.0 \\
Continued & & & & 70 & $26^{\circ} 30^{\prime} \mathrm{N}$ & $149^{\circ} 20^{\prime} \mathrm{E}$ & 1267.5 \\
36 & $6^{\circ} 00^{\prime} \mathrm{N}$ & $148^{\circ} 16^{\prime} \mathrm{N}$ & 405.3 & 73 & $28^{\circ} 30^{\prime} \mathrm{N}$ & $149^{\circ} 20^{\prime} \mathrm{E}$ & 1518.8 \\
40 & $8^{\circ} 00^{\prime} \mathrm{N}$ & $149^{\circ} 10^{\prime} \mathrm{N}$ & 439.5 & 76 & $30^{\circ} 11^{\prime} \mathrm{N}$ & $148^{\circ} 03^{\prime} \mathrm{E}$ & 1659.9 \\
45 & $10^{\circ} 00^{\prime} \mathrm{N}$ & $149^{\circ} 20^{\prime} \mathrm{N}$ & 514.0 & 79 & $31^{\circ} 43^{\prime} \mathrm{N}$ & $146^{\circ} 07^{\prime} \mathrm{E}$ & 1615.3 \\
48 & $11^{\circ} 50^{\prime} \mathrm{N}$ & $149^{\circ} 20^{\prime} \mathrm{N}$ & 622.6 & 81 & $32^{\circ} 41^{\prime} \mathrm{N}$ & $144^{\circ} 54^{\prime} \mathrm{E}$ & 1646.5 \\
51 & $13^{\circ} 0^{\prime} \mathrm{N}$ & $149^{\circ} 20^{\prime} \mathrm{N}$ & 782.7 & 83 & $33^{\circ} 40^{\prime} \mathrm{N}$ & $143^{\circ} 40^{\prime} \mathrm{E}$ & 1663.9 \\
54 & $15^{\circ} 0^{\prime} \mathrm{N}$ & $149^{\circ} 20^{\prime} \mathrm{N}$ & 989.8 & 85 & $34^{\circ} 11^{\prime} \mathrm{N}$ & $142^{\circ} 43^{\prime} \mathrm{E}$ & 1576.2 \\
58 & $18^{\circ} 0^{\prime} \mathrm{N}$ & $149^{\circ} 20^{\prime} \mathrm{N}$ & 1059.8 & 88 & $34^{\circ} 45^{\prime} \mathrm{N}$ & $141^{\circ} 39^{\prime} \mathrm{E}$ & 888.5 \\
61 & $20^{\circ} 0^{\prime} \mathrm{N}$ & $149^{\circ} 20^{\prime} \mathrm{N}$ & 1214.5 & 90 & $34^{\circ} 55^{\prime} \mathrm{N}$ & $141^{\circ} 12^{\prime} \mathrm{E}$ & 914.8 \\
64 & $22^{\circ} 30^{\prime} \mathrm{N}$ & $149^{\circ} 20^{\prime} \mathrm{N}$ & 1319.5 & 92 & $35^{\circ} 06^{\prime} \mathrm{N}$ & $140^{\circ} 54^{\prime} \mathrm{E}$ & 692.0 \\
\hline
\end{tabular}

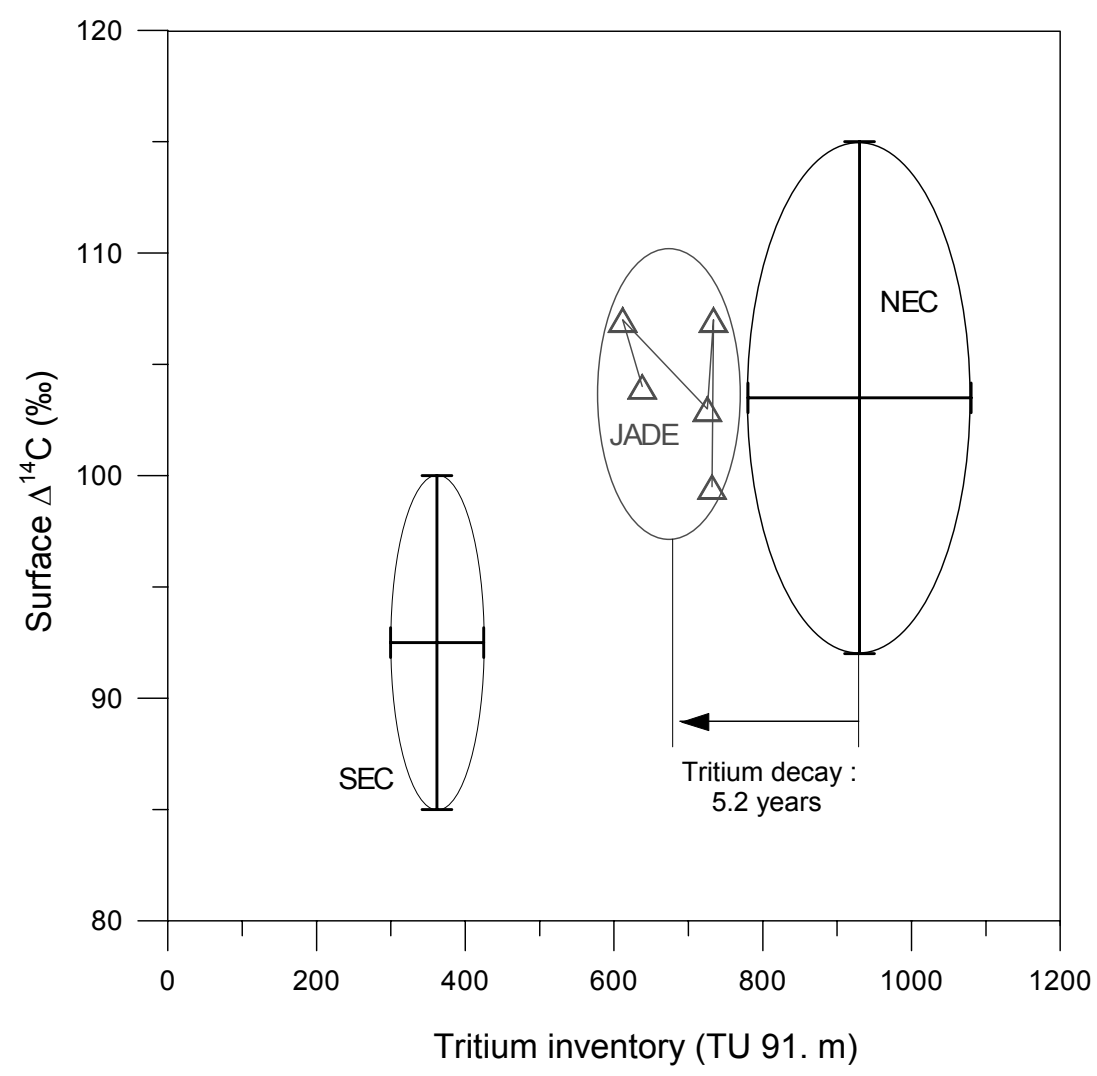

Figure 7 Diagram of the JADE- 89 surface $\Delta^{14} \mathrm{C}$ versus tritium inventory. The 2 Pacific end-members (NEC and SEC) are also indicated with their respective uncertainty.

The corresponding bulk residence time $\tau$ of North Pacific waters in the Indonesian seas is given by $\tau=-\lambda^{-1} \ln (0.75)$, where $\lambda$ is the decay constant for tritium, leading to a residence time of $5.2 \mathrm{yr}$. This estimate is certainly a lower limit since it neglects the tritium added by rain and water-vapor exchange at the air-sea interface. This residence time $\tau$ can be related in a simple manner to the value of the throughflow $\Phi$ by the equation: $\tau=\mathrm{V} / \Phi$, where $V$ is the volume of the Indonesian waters 
involved in the Pacific-Indian water transport. This volume roughly corresponds to the average surface area of the Indonesian seas $\left(\approx 2 \times 10^{6} \mathrm{~km}^{2}\right.$; GEBCO 1984) multiplied by the mean depth of the sills crossed by the Indonesian waters entering the Indian Ocean. Taking an average depth of $1500 \mathrm{~m}$ (Gordon et al. 2003), the $5.2 \mathrm{yr}$ minimum residence time translates into an upper value of throughflow $\Phi \sim 18 \times 10^{6} \mathrm{~m}^{3} / \mathrm{s}$. This value is in surprisingly good agreement with the geostrophic transport calculated by Fieux et al. (1994) for August 1989: $18.6 \times 10^{6} \mathrm{~m}^{3} / \mathrm{s}$. This agreement may be somewhat fortuitous considering the experimental uncertainties and the crudeness of the above calculation. However, it strongly supports our interpretation of the tritium and ${ }^{14} \mathrm{C}$ data, which discards any significant involvement of the South Pacific waters in the Pacific-Indonesian throughflow at the time of the JADE- 89 cruise.

\section{CONCLUSION}

The ${ }^{14} \mathrm{C}$ and ${ }^{3} \mathrm{H}$ measurements performed in the framework of the Java-Australia Dynamics Experiment (JADE) in August 1989, on a transect between Australia and Bali, bridge the gap between the western Pacific and the Eastern Indian Ocean tracer data. The results complement the data on both sides of the Indonesian throughflow obtained during the WOCE program in 1993/1995 and are fully consistent with the WOCE tracer results.

The Indonesian throughflow has been the focus of numerous studies, including hydrographic work, tracer data, drifters tracks, and circulation models. Most of these studies point to a mainly North Pacific origin of the waters that cross the Indonesian seaway from the Pacific to the Indian Ocean. The present tracer data fully support these conclusions. Furthermore, our results indicate that, at least at the time of the JADE survey, the south Pacific component was virtually absent from the tracer signal recorded at the exit of the throughflow.

\section{ACKNOWLEDGEMENTS}

This work was carried out under the French-Indonesian cooperation program led by A G Ilahude (LIPI) and M Fieux (CNRS-INSU). We acknowledge the support of the Indonesian BPPT and the Terres Australes et Antarctiques Françaises (TAAF). We also thank R Key (Princeton University) for his review and insightful comments.

\section{REFERENCES}

Bard E, Arnold M, Maurice P, Duplessy JC. 1987. Measurements of bomb radiocarbon in the ocean by means of accelerator mass spectrometry: technical aspects. Nuclear Instruments and Methods in Physics Research B 29:297-301.

Broecker WS, Peng TH, Östlund G, Stuiver M. 1985. The distribution of bomb radiocarbon in the ocean. Journal of Geophysical Research 90:6953-70.

Broecker WS, Patzert WC, Toggweiler JR, Stuiver M. 1986a. Hydrography, chemistry and radioisotopes in the Southeast Asian basins. Journal of Geophysical Research 91:14,345-54.

Broecker WS, Peng TH, Östlund G. 1986b. The distribution of bomb tritium in the ocean. Journal of Geophysical Research 91:14,331-44.

Broecker WS, Sutherland S, Smethie W, Peng TH, Östlund G. 1995. Oceanic radiocarbon: separation of the natural and bomb components. Global
Biogeochemical Cycles 9:263-88.

Druffel ERM. 1987. Bomb radiocarbon in the Pacific: annual and seasonal timescale variations. Journal of Marine Research 45:667-98.

Ffield A, Gordon AL. 1992. Vertical mixing in the Indonesian thermocline. Journal of Physical Oceanography 22:184-95.

Fieux M, Andrié C, Delecluse P, Ilahude AG, Kartavseff A, Mantisi F, Molcard R, Swallow JC. 1994. Measurements within the Pacific-Indian Oceans throughflow region. Deep-Sea Research 41:1091-130.

Fine RA. 1985. Direct evidence using tritium data for throughflow from the Pacific into the Indian Ocean. Nature 315:478-80.

Fine RA, Lukas R, Bingham FM, Warner MJ, Gammon RH. 1994. The western equatorial Pacific: a water mass crossroads. Journal of Geophysical Research 99: $25,063-80$. 
GEBCO (General Bathymetric Chart of the Oceans, Department of Fisheries and Oceans). 1984. Canadian Hydrographic Chart Distribution Office, Canadian Government Publishing Center, Ottawa, Canada.

Gordon AL. 1986. Interocean exchange of thermocline water. Journal of Geophysical Research 91:5037-46.

Gordon AL, Fine RA. 1996. Pathways of water between the Pacific and Indian Oceans in the Indonesian seas. Nature 379:146-9.

Gordon AL, Giulivi CF, Ilahude AG. 2003. Deep topographic barriers within the Indonesian seas. Deep-Sea Research 50:2205-28.

Jean-Baptiste P, Andrié C, Lelu M. 1989. Helium diffusion through glass. Glass Technology 30:228-30.

Jean-Baptiste P, Mantisi F, Dapoigny A, Stievenard M. 1992. Design and performance of a mass spectrometric facility for measuring helium isotopes in natural waters and for low-level tritium determination by the helium-3 ingrowth method. Applied Radiations and Isotopes 43:881-91.

Jean-Baptiste P, Fieux M, Dapoigny A, Ilahude AG. 1997. An eastern Indian Ocean ${ }^{3} \mathrm{He}$ section from Australia to Bali: evidence for a deep Pacific-Indian throughflow. Geophysical Research Letters 24:257780.

Jenkins WJ. 2002. World Ocean Circulation Experiment (WOCE) one-time cruises data [internet]. http:/ whpo.ucsd.edu/data/onetime.

Key RM, Quay P, Schlosser P, McNichol AP, Von Reden KF, Schneider RJ, Elder KL, Stuiver M, Ostlund HG. 1996. WOCE radiocarbon IV: Pacific Ocean results; P10, P13N, P14C, P18, P19 \& S4P. Radiocarbon 38(2):239-392.

Kumamoto Y, Murata A, Saito C, Honda M, Kusakabe M. 2002. Bomb radiocarbon invasion into the northwestern North Pacific. Deep-Sea Research II 49: 5339-51.
Leboucher V, Orr J, Jean-Baptiste P, Arnold M, Monfray P, Tisnerat-Laborde N, Poisson A, Duplessy JC. 1999. Oceanic radiocarbon between Antarctica and South Africa along WOCE section I6 at $30^{\circ}$ E. Radiocarbon 41(1):51-73.

McCartney MS. 1982. The subtropical recirculation of mode waters. Journal of Marine Research 40:427-64.

Moore MD, Schrag DP, Kashgarian M.1997. Coral radiocarbon constraints on the source of the Indonesian throughflow. Journal of Geophysical Research 102: 12,359-65.

Rubin SI, Key RM. 2002. Separating natural and bombproduced radiocarbon in the ocean: the potential alkalinity method. Global Biogeochemical Cycles 16: 1105-24.

Schlosser P. 2002. World Ocean Circulation Experiment (WOCE) one-time cruises data [internet]. http:/ whpo.ucsd.edu/data/onetime.

Toggweiler JR, Dixon K, Bryan K.1989. Simulations of radiocarbon in a coarse-resolution world ocean model: distributions of bomb-produced carbon-14. Journal of Geophysical Research 94:8243-64.

Toole JM, Millard RC, Wang Z, Pu S. 1990. Observations of the Pacific north equatorial current bifurcation at the Philippines coast. Journal of Physical Oceanography 20:307-18.

Top Z, Gordon A, Jean-Baptiste P, Fieux M, Ilahude AG, Muchtar M. 1997. Helium-3 in Indonesians seas: inferences on deep pathways. Geophysical Research Letters 24:547-50.

Warren BA. 1981. Transindian hydrographic section at Lat. $18^{\circ} \mathrm{S}$ : Property distributions and circulation in the South Indian Ocean. Deep-Sea Research 28:759-88.

Weiss W, Roether W. 1980. The rate of tritium input to the world oceans. Earth and Planetary Science Letters 49:435-46. 